\title{
Content of fatty acids in erythrocytes of blood of cows before and after calving and their correction
}

\section{G. Sedilo, A. Dyachenko \\ Institute of agriculture of region of Carpathians of NAAN of Ukraine}

The purpose. To study in erythrocytes of cows of different level of milk productivity the content of fatty acids (FA) in before- and after-postnatal periods in connection with reproductive function and at injection of extract of aloe. Methods. Chromatographic, statistical. Results. At $25-30^{\text {th }}$ day before calving the ratio of saturated and nonsaturated FA at more productive cows is less than that at less productive ones. Injection of hypodermically extract of aloe at $25-30^{\text {th }}$ day before labors decreases in an organism the content of saturated FA and increases the level of monononsaturated and polynonsaturated FA. At the same time at 5 $-7^{\text {th }}$ day before calving authentically increases the content of linolic, linolenic, eicozatrienic and eicozateraenic (arachidonic) FA and on $10-14^{\text {th }}$ day after it - the content of linolic, linolenic, eicozatrienic and eicozateraenic (arachidonic), and docozapentaenic. Conclusions. At action of extract of aloe the content of nonsaturated FA in erythrocytes of cows at $5-7^{\text {th }}$ day before calving and on $10-14^{\text {th }}$ day after it increases. The content of polynonsaturated FA increases due to acids $\omega-3$ and $\omega-6$. Injection of extract of an aloe at $25-30^{\text {th }}$ day before calving positively influences puerperal period, restore of high-grade sexual cycles and breeding efficiency.

Key words: cows, fatty acids, extract of aloe, milk productivity, breeding capacity.

Sexual function of females is aimed at creating in her genitals and the whole body of the animal favorable conditions for fertilization, pregnancy, birth, babies and breastfeeding in the postnatal period. The mechanism of realization of a female, her reproductive ability is too complex. During pregnancy, birth and the postpartum period, profound changes in biochemical processes, hormonal balance, immune reactivity are occured in its organism [1]. It is known that in high yielding cows is an inverse relationship between productivity and reproductive function, due to increased sensitivity of highly productive animals to environmental factors, decrease in natural resistance and also the influence of the lactation dominant, which suppresses sexual function in consequence of hormonal changes [2, 3].

The last month of pregnancy is critical physiological period in cows that substantially affects on state of the immune system of the organism and the course of the postpartum involution of the birth canal $[2,4,5]$. Moreover, in the conditions of intensification of livestock production the negative impact of stress factors of different nature, which lead to the violation of physiological functions and biochemical processes in the organism of animals increases. [1, 6]. The strengthening of processes of lipid peroxidation, decreased activity of the antioxidant defense system and immunobiological reactivity lying in the basis for these violations [7]. Therefore, a study should be made to find objective criteria for the assessment of physiological and biochemical processes in the organism and development methods of their correction to improve reproductive function of cows. One of the metrics by which we objectively determine the physiological condition and resistance of the organism of cows can serve the content of fatty acids which largely determine the immunological reactivity of the organism, increase the resistance of animals to adverse environmental factors and to impact on productive qualities of cows [8-12]. In organism of humans and animals the fatty acid content, value and dynamics study for their content in the membranes of cells. In particular, studies using erythrocyte membranes (as a basic model for research) that reflects the content and features in all cells and tissues of the organism [13]. It is established that in the erythrocytes of cows the lipids contains only in the membrane [14]. This suggests that the fatty acid composition of erythrocytes is an objective measure and can be used to assess the physiological state of the cows organism. 
To ensure optimum flow of biochemical and immunological processes in the organism of cows in the dry and postpartum period in our opinion should be used drugs of natural origin, which are aimed at stimulating your own organism's defense mechanisms [15]. This purpose deserves attention is the use of tissue preparations and of Pharmacopoeia aloe extract, which stimulates the metabolism, increases the resistance and normalizes physiological functions of the organism, promotes regeneration of cells and tissues [16, 17].

The purpose - to study in erythrocytes of cows of different level of milk production the content of fatty acids in pre- and postpartum periods in connection with the reproductive function and on the effect of aloe extract.

Materials and methods of research. The research was conducted in SFEF "Radekhiv" Institute of Agriculture of Carpathian Region of NAAS on two groups of clinically healthy, mature cows of Ukrainian Black-Speckled dairy breed of western inbred type, analogues for age and live weight, 20 animals in each. The results of the previous lactation in the first group cows were selected with milk yield $4800-5200 \mathrm{~kg}$ per 305 days of lactation (high productive, group I), the second $-3850-4150 \mathrm{~kg}$ (low productive, group II). Each group of cows were divided into control and experimental groups. Cows of the experimental group (E) for 2530 days before the expected birth were injected subcutaneously twice with an interval of 5-7 days Pharmacopoeia aloe extract (certificate of registration of the product № UA/5896/01/01 from 19.02.07) a dose of $20 \mathrm{ml}$ per animal, and the control $(\mathrm{K})$ - the same amount of isotonic sodium chloride solution.

Material for the study was the blood that was taken from five animals of each group 25-30 and 5-7 days before expected birth and 10-14 days after. In the obtained erythrocyte suspension on chromatograph it was "Chrom-5" determined the concentration of fatty acids by the method J. Rivis et al. (2010) [18].

The course of postnatal period for duration resumption of ovulatory cycles and service period and fertilization from the first insemination were in studied cows. The obtained data were processed statistically using MS-Excel.

The results of the research. As a result of researches it is revealed that within 25 to 30 days prior to calving and prior to parenteral administration of the investigated solutions in blood erythrocytes of highly cows compared to low productive the content of fatty acids is higher mainly due to monounsaturated and polyunsaturated FA, which determines the differences of the index of saturation of lipids $(1,77 \mathrm{vs} 1,87)$. That is, the ratio of saturated to unsaturated fatty acids of high yielding cows is less than in low productive ones (tab. 1).

1. Content of fatty acids in blood erythrocytes of cows for $25-30$ days before calving, $g^{-3} / l(n=5, M \pm m)$

\begin{tabular}{|l|c|c|c|c|}
\hline \multirow{2}{*}{\multicolumn{1}{c|}{$\begin{array}{c}\text { Fatty acids } \\
\text { and their abbreviation }\end{array}$}} & \multicolumn{4}{c|}{ Group of cows } \\
\cline { 2 - 5 } & \multicolumn{2}{|c|}{ low productivity } & \multicolumn{2}{c|}{ high productivity } \\
\cline { 2 - 5 } & control & experimental & control & experimental \\
\hline Caprilic acid, 8:0 & $5,5 \pm 0,23$ & $5,7 \pm 0,18$ & $5,8 \pm 0,26$ & $5,8 \pm 0,33$ \\
\hline Capric acid, 10:0 & $7,8 \pm 0,35$ & $7,7 \pm 0,44$ & $8,5 \pm 0,35$ & $8,6 \pm 0,41$ \\
\hline Lauric acid, 12:0 & $10,2 \pm 0,52$ & $10,3 \pm 0,44$ & $11,3 \pm 0,55$ & $11,3 \pm 0,67$ \\
\hline Myristic acid, 14:0 & $16,5 \pm 0,81$ & $16,5 \pm 0,67$ & $18,1 \pm 0,75$ & $18,0 \pm 0,67$ \\
\hline Pentadecanoic acid, 15:0 & $14,9 \pm 0,81$ & $14,8 \pm 0,90$ & $16,3 \pm 0,84$ & $16,1 \pm 0,84$ \\
\hline Palmitic acid, 16:0 & $1100,8 \pm 57,97$ & $1099,6 \pm 58,48$ & $1115,9 \pm 55,67$ & $1109,0 \pm 54,98$ \\
\hline Palmitoleic acid, 16:1 & $25,0 \pm 1,36$ & $24,7 \pm 1,30$ & $27,5 \pm 1,30$ & $27,2 \pm 1,36$ \\
\hline Stearic acid, 18:0 & $556,2 \pm 31,21$ & $553,8 \pm 30,98$ & $613,5 \pm 32,65$ & $612,4 \pm 32,67$ \\
\hline Oleic acid, 18:1 & $325,1 \pm 18,72$ & $323,8 \pm 19,38$ & $357,7 \pm 18,31$ & $358,9 \pm 18,32$ \\
\hline Linoleic acid, 18:2 & $313,6 \pm 18,13$ & $314,8 \pm 17,57$ & $345,9 \pm 18,66$ & $347,9 \pm 18,9$ \\
\hline Linolenic acid, 18:3 & $113,6 \pm 6,16$ & $111,7 \pm 6,56$ & $126,7 \pm 6,49$ & $124,4 \pm 6,27$ \\
\hline Arachidic acid, 20:0 & $9,8 \pm 0,38$ & $9,6 \pm 0,36$ & $10,7 \pm 0,38$ & $10,5 \pm 0,32$ \\
\hline Eicosenic acid, 20:1 & $9,2 \pm 0,49$ & $9,1 \pm 0,52$ & $10,1 \pm 0,46$ & $9,9 \pm 0,44$ \\
\hline Eicosadienoic acid, 20:2 & $29,2 \pm 1,47$ & $28,5 \pm 1,33$ & $32,1 \pm 1,45$ & $32,5 \pm 1,47$ \\
\hline Eicosatrienoic acid, 20:3 & $33,1 \pm 1,79$ & $33,7 \pm 1,65$ & $36,5 \pm 1,85$ & $36,0 \pm 1,85$ \\
\hline
\end{tabular}




\begin{tabular}{|l|c|c|c|c|}
\hline $\begin{array}{l}\text { Eicosatetraenoic } \\
\text { (arachidonic) acid, 20:4 }\end{array}$ & $8,9 \pm 0,74$ & $8,8 \pm 0,76$ & $9,7 \pm 0,71$ & $9,5 \pm 0,67$ \\
\hline Eicosapentaenoic acid, 20:5 & $11,7 \pm 0,90$ & $11,5 \pm 0,90$ & $13,2 \pm 0,90$ & $13,4 \pm 0,87$ \\
\hline Docosadienoic acid, 22:2 & $6,0 \pm 0,32$ & $5,8 \pm 0,29$ & $6,5 \pm 0,32$ & $6,7 \pm 0,29$ \\
\hline Docosatrienoic acid, 22:3 & $7,4 \pm 0,38$ & $7,3 \pm 0,44$ & $8,1 \pm 0,38$ & $8,3 \pm 0,38$ \\
\hline Docosatetraenoic acid, 22:4 & $10,5 \pm 0,55$ & $10,7 \pm 0,58$ & $11,5 \pm 0,61$ & $11,3 \pm 0,64$ \\
\hline Docosapentaenoic acid, 22:5 & $12,4 \pm 0,75$ & $12,2 \pm 0,72$ & $13,3 \pm 0,52$ & $13,1 \pm 0,55$ \\
\hline Docosahexaenoic acid, 22:6 & $16,3 \pm 0,62$ & $16,4 \pm 0,92$ & $18,2 \pm 0,90$ & $17,9 \pm 0,87$ \\
\hline General content of fatty acids & 2643,7 & 2637,0 & 2817,1 & 2808,7 \\
\hline Including saturated & 1721,7 & 1718,0 & 1800,1 & 1791,7 \\
\hline monounsaturated & 359,3 & 357,6 & 395,3 & 396,0 \\
\hline polyunsaturated & 562,7 & 561,4 & 621,7 & 621,0 \\
\hline \multicolumn{1}{|c|}{$-3 /-6$} & 0,44 & 0,43 & 0,44 & 0,44 \\
\hline
\end{tabular}

In the control groups of animals before calving (5-7 days) there is found trend to reduction in the erythrocytes the content of fatty acids in high-yielding animals due to unsaturated FA, low productive - at the expense of saturated fatty acids with an even number of carbon atoms in the chain and unsaturated fatty acids (table. 2). The increase in the ratio of saturated to unsaturated fatty acids of high yielding cows is substantial $(8,0 \%)$, low productive - small $(3,2 \%)$.

2. Content of fatty acids in blood erythrocytes of cows for 5-7 days before calving, $g^{-3} / l(n=5, M \pm m)$

\begin{tabular}{|l|c|c|c|c|}
\hline \multirow{2}{*}{\multicolumn{1}{c|}{ Fatty acids }} & \multicolumn{4}{c|}{ Group of cows } \\
\cline { 2 - 5 } & \multicolumn{2}{|c|}{ low productivity } & \multicolumn{2}{c|}{ high productivity } \\
\cline { 2 - 5 } & control & experimental & control & experimental \\
\hline Caprilic acid, 8:0 & $5,2 \pm 0,29$ & $5,0 \pm 0,26$ & $5,7 \pm 0,35$ & $5,4 \pm 0,38$ \\
\hline Capric acid, 10:0 & $7,5 \pm 0,40$ & $7,2 \pm 0,43$ & $8,2 \pm 0,46$ & $7,9 \pm 0,46$ \\
\hline Lauric acid, 12:0 & $9,7 \pm 0,52$ & $9,3 \pm 0,49$ & $10,8 \pm 0,64$ & $10,4 \pm 0,58$ \\
\hline Myristic acid, 14:0 & $16,0 \pm 0,90$ & $15,6 \pm 0,90$ & $17,3 \pm 1,13$ & $16,9 \pm 1,05$ \\
\hline Pentadecanoic acid, 15:0 & $14,4 \pm 0,55$ & $14,0 \pm 0,55$ & $15,9 \pm 1,19$ & $15,5 \pm 1,19$ \\
\hline Palmitic acid, 16:0 & $999,1 \pm 51,62$ & $951,2 \pm 52,04$ & $1145,0 \pm 37,73$ & $1132,9 \pm 41,62$ \\
\hline Palmitoleic acid, 16:1 & $26,2 \pm 1,47$ & $27,3 \pm 1,79$ & $28,3 \pm 1,65$ & $30,4 \pm 1,71$ \\
\hline Stearic acid, 18:0 & $526,8 \pm 34,26$ & $484,8 \pm 33,15$ & $561,4 \pm 29,65$ & $512,7 \pm 30,73$ \\
\hline Oleic acid, 18:1 & $302,8 \pm 17,31$ & $313,8 \pm 16,24$ & $328,8 \pm 17,98$ & $345,6 \pm 18,42$ \\
\hline Linoleic acid, 18:2 & $260,3 \pm 15,25$ & $314,8 \pm 10,71^{*}$ & $318,2 \pm 18,56$ & $360,4 \pm 12,19$ \\
\hline Linolenic acid, 18:3 & $101,8 \pm 5,90$ & $125,5 \pm 5,99^{*}$ & $114,0 \pm 6,29$ & $142,9 \pm 6,73^{*}$ \\
\hline Arachidic acid, 20:0 & $9,2 \pm 0,52$ & $9,0 \pm 0,50$ & $10,2 \pm 0,52$ & $9,8 \pm 0,47$ \\
\hline Eicosenic acid, 20:1 & $9,0 \pm 0,49$ & $9,4 \pm 0,55$ & $9,4 \pm 0,52$ & $9,9 \pm 0,58$ \\
\hline Eicosadienoic acid, 20:2 & $8,2 \pm 0,46$ & $8,5 \pm 0,49$ & $9,1 \pm 0,49$ & $9,6 \pm 0,52$ \\
\hline Eicosatrienoic acid, 20:3 & $26,0 \pm 1,25$ & $31,7 \pm 1,39^{*}$ & $28,7 \pm 1,59$ & $34,3 \pm 1,19^{*}$ \\
\hline Eicosatetraenoic & & & & \\
(arachidonic) acid, 20:4 & $30,1 \pm 1,67$ & $37,7 \pm 1,42^{*}$ & $32,4 \pm 1,68$ & $39,2 \pm 1,71^{*}$ \\
\hline Eicosapentaenoic acid, 20:5 & $10,4 \pm 0,48$ & $11,8 \pm 0,66$ & $12,6 \pm 0,69$ & $14,8 \pm 0,69$ \\
\hline Docosadienoic acid, 22:2 & $5,6 \pm 0,32$ & $6,0 \pm 0,35$ & $6,1 \pm 0,32$ & $6,6 \pm 0,35$ \\
\hline Docosatrienoic acid, 22:3 & $7,0 \pm 0,35$ & $7,5 \pm 0,38$ & $7,5 \pm 0,43$ & $7,9 \pm 0,43$ \\
\hline Docosatetraenoic acid, 22:4 & $8,6 \pm 0,43$ & $9,2 \pm 0,41$ & $10,8 \pm 0,69$ & $11,9 \pm 0,72$ \\
\hline Docosapentaenoic acid, 22:5 & $11,7 \pm 0,64$ & $13,2 \pm 0,40$ & $12,4 \pm 0,72$ & $14,1 \pm 0,40$ \\
\hline Docosahexaenoic acid, 22:6 & $15,8 \pm 0,87$ & $17,6 \pm 0,40$ & $16,7 \pm 0,87$ & $18,4 \pm 0,35$ \\
\hline General content of fatty acids & 2411,4 & 2430,1 & 2709,5 & 2757,5 \\
\hline
\end{tabular}




\begin{tabular}{|l|c|c|c|c|}
\hline Including saturated & 1587,9 & 1496,1 & 1774,5 & 1711,5 \\
\hline monounsaturated & 338,0 & 350,5 & 366,5 & 385,9 \\
\hline polyunsaturated & 485,5 & 583,5 & 568,5 & 660,1 \\
\hline \multicolumn{1}{|c|}{$-3 /-6$} & 0,47 & 0,46 & 0,44 & 0,47 \\
\hline
\end{tabular}

Note: hereinafter ${ }^{*}-p<0,02-0,05 ;{ }^{* *}-p<0,01 ;{ }^{* * *}-p<0,001$.

For 5-7 days before calving with low- and high-productive cows, which were injected with aloe extract, the content of saturated fatty acids with an even number of carbon atoms is lower and the level of monounsaturated and polyunsaturated fatty acids is higher (mainly due to the fatty acids family $\omega-9$ and family $\omega-6)$. This leads to a significant decrease in saturation index of the lipids erythrocytes. In the blood erythrocytes of the low productive cows of the experimental group compared with the control, the ratio of polyunsaturated fatty acids of the family $\omega-3$ to polyunsaturated fatty acids family $\omega-6$ almost unchanged and highly productive ones - increases.

After calving (10-14 days) in comparison with the previous period of research the content of fatty acids in blood erythrocytes of cows of the control groups decreased in cows with milk productivity $3850-4150 \mathrm{~kg}$, level of fatty acids decreased by $4,7 \%$, and from $4800-5200 \mathrm{~kg}-$ on $7,4 \%$ (table 3 ). These changes in low productive animals was occured due to a slight decline in the content of saturated fatty acids with an even number of carbon atoms in the chain $(3,9 \%)$ and monounsaturated fatty acids $(3,6 \%)$, and average degree of reduction in polyunsaturated fatty acids $(7,6 \%)$. In high yielding cows there is a uniform, almost identical in relative terms the reduction of all fatty acids. As a consequence, the index of saturation of lipids in the first ones slightly increases $(1,93$ vs 1,97$)$, in the second ones is not changed.

At 10-14 days after calving with low- and high-productive cows which used the aloe extract, the content of saturated fatty acids with an even number of carbon atoms is lower and the level of monounsaturated and polyunsaturated fatty acids is higher (mainly due to, respectively, the fatty acids of the family $\omega-9$ and family $\omega-6)$. This leads to a significant reduction of the index of saturation of the lipids erythrocytes in high- and lowyielding cows.

3. Content of fatty acids in blood erythrocytes of cows at 10-14 days after calving, $g^{-3} / I(n=5, M \pm m)$

\begin{tabular}{|l|c|c|c|c|}
\hline \multirow{2}{*}{\multicolumn{1}{c|}{ Fatty acids }} & \multicolumn{4}{c|}{ Group of cows } \\
\cline { 2 - 5 } & \multicolumn{2}{|c|}{ low productivity } & \multicolumn{2}{c|}{ high productivity } \\
\cline { 2 - 5 } & control & control & control & control \\
\hline Caprilic acid, 8:0 & $5,0 \pm 0,29$ & $4,7 \pm 0,29$ & $5,4 \pm 0,32$ & $5,1 \pm 0,32$ \\
\hline Capric acid, 10:0 & $7,2 \pm 0,40$ & $6,9 \pm 0,38$ & $7,8 \pm 0,49$ & $7,5 \pm 0,49$ \\
\hline Lauric acid, 12:0 & $9,2 \pm 0,46$ & $9,0 \pm 0,38$ & $10,3 \pm 0,52$ & $9,8 \pm 0,49$ \\
\hline Myristic acid, 14:0 & $15,5 \pm 0,87$ & $15,2 \pm 0,85$ & $16,9 \pm 0,98$ & $16,4 \pm 0,95$ \\
\hline Pentadecanoic acid, 15:0 & $13,6 \pm 0,75$ & $13,2 \pm 0,72$ & $15,1 \pm 0,87$ & $14,7 \pm 0,90$ \\
\hline Palmitic acid, 16:0 & $956,4 \pm 54,33$ & $914,6 \pm 50,57$ & $1055,6 \pm 61,81$ & $1008,8 \pm 62,01$ \\
\hline Palmitoleic acid, 16:1 & $24,3 \pm 1,41$ & $25,8 \pm 1,49$ & $25,6 \pm 1,44$ & $26,6 \pm 1,42$ \\
\hline Stearic acid, 18:0 & $509,1 \pm 27,68$ & $466,6 \pm 27,82$ & $522,3 \pm 28,12$ & $506,4 \pm 28,16$ \\
\hline Oleic acid, 18:1 & $292,8 \pm 14,39$ & $313,1 \pm 12,77$ & $303,8 \pm 16,17$ & $323,8 \pm 16,51$ \\
\hline Linoleic acid, 18:2 & $240,6 \pm 14,26$ & $294,0 \pm 10,78^{*}$ & $300,5 \pm 16,11$ & $371,6 \pm 10,73^{*}$ \\
\hline Linolenic acid, 18:3 & $94,1 \pm 4,91$ & $116,0 \pm 4,87^{*}$ & $102,7 \pm 5,11$ & $136,0 \pm 5,18^{*}$ \\
\hline Arachidic acid, 20:0 & $9,0 \pm 0,49$ & $8,7 \pm 0,40$ & $9,8 \pm 0,49$ & $9,4 \pm 0,46$ \\
\hline Eicosenic acid, 20:1 & $8,7 \pm 0,46$ & $9,0 \pm 0,44$ & $9,0 \pm 0,49$ & $9,4 \pm 0,49$ \\
\hline Eicosadienoic acid, 20:2 & $8,0 \pm 0,43$ & $8,4 \pm 0,43$ & $8,7 \pm 0,46$ & $9,1 \pm 0,43$ \\
\hline Eicosatrienoic acid, 20:3 & $22,3 \pm 1,24$ & $27,4 \pm 1,25^{*}$ & $25,3 \pm 1,41$ & $31,3 \pm 1,53^{*}$ \\
\hline Eicosatetraenoic \\
(arachidonic) acid, 20:4 & $27,1 \pm 1,53$ & $33,3 \pm 1,57^{*}$ & $29,0 \pm 1,51$ & $36,1 \pm 1,79^{*}$ \\
\hline
\end{tabular}




\begin{tabular}{|l|c|c|c|c|}
\hline Eicosapentaenoic acid, 20:5 & $6,7 \pm 0,38$ & $7,1 \pm 0,35$ & $7,1 \pm 0,40$ & $7,4 \pm 0,38$ \\
\hline Docosadienoic acid, 22:2 & $8,1 \pm 0,43$ & $8,6 \pm 0,49$ & $9,5 \pm 0,49$ & $10,4 \pm 0,41$ \\
\hline Docosapentaenoic acid, 22:5 & $11,1 \pm 0,64$ & $13,0 \pm 0,58^{*}$ & $11,8 \pm 0,69$ & $13,5 \pm 0,52$ \\
\hline Docosahexaenoic acid, 22:6 & $15,0 \pm 0,81$ & $17,5 \pm 0,87$ & $16,0 \pm 0,81$ & $18,7 \pm 0,90$ \\
\hline General content of fatty acids & 2299,2 & 2329,4 & 2509,0 & 2591,9 \\
\hline Including saturated & 1525,0 & 1438,9 & 1642,9 & 1578,1 \\
\hline monounsaturated & 325,8 & 347,9 & 338,4 & 359,8 \\
\hline polyunsaturated & 448,4 & 542,6 & 527,7 & 654,0 \\
\hline \multicolumn{1}{|c|}{$-3 /-6$} & 0,48 & 0,47 & 0,43 & 0,44 \\
\hline
\end{tabular}

Based on the analysis of changes in individual fatty acids it was found that for 5-7 days before calving in cows with milk yield $3850-4150 \mathrm{~kg}$ of the experimental group compared to the control one is higher levels of linoleic and linolenic acids, while animals with milk yield 4800-5200 kg - only linolenic one. Also in both groups the concentration eicosatrienoic and eicosatetraenoic (arachidonic) fatty acids was the higher. At 1014 days after calving is was established significantly higher content of linoleic and linolenic acids and their derivatives, namely: eicosatrienoic, eicosatetraenoic (arachidonic), and docosapentaenoic (in cows with milk yields $3850-4150 \mathrm{~kg}$ of milk) and eicosatrienoic, eicosatetraenoic-arachidonic and eicosapentaenoic acids (in animals with milk yield $4800-5200 \mathrm{~kg}$ ).

From literature data it is known that linoleic, linolenic and arachidonic polyunsaturated fatty acids increase the organism resistance to adverse environmental factors. They also show the function of modulators of the immune system, by activating the function of immunocompetent cells, contribute to the normalization of the immune system over increasing resistance [19, 20]. Fatty acids show a specific effect on the immune system of the organism. Modern studies confirm the involvement of lipids in the regulation of immune responses initiation, especially of individual polyunsaturated fatty acids (linoleic, linolenic, eicosatetraenoic) [20]. They act as precursors for prostaglandins, thromboxane, leukotriens, icosanoids synthesis, which in turn are involved in the regulation of the immune response[8, 19-21]. Increasing the amount of linoleic, linolenic and arachidonic fatty acids indicates an increase of resistance and the total immunological reactivity of the organism. Polyunsaturated fatty acids of linoleic row entering into the structure of the cell and cytoplasmic membranes and lipoproteins-transfer determine their physic and chemical and functional properties [8, 19, 20]. That is likely to increase concentrations of eicosapentaenoic, eicosatetraenoic (arachidonic), and docosatetraenoic acids may indicate the significant increase in the concentration in the organism of cows of icosanoids especially prostaglandins (which are directly related to their reproductive function) and increase of nonspecific resistance and adaptive capacity of the animal organism to adverse environmental factors.

It is proved that the membrane acts as a permeability barrier, and lipids, which are an integral part of cellular structures involved in the control of the internal environment of the cell and its relationship with the external environment [22]. While polyunsaturated fatty acids, included into the structure of biomembranes, define the specific function of cells and provide membrane fluidity and affect on the functioning of the immune system $[8,19,20]$. That is, the increase in blood erythrocytes of cows, which used the aloe extract absolute and relative content of polyunsaturated fatty acids indicates an increase in permeability of cell membranes and increase metabolic exchange between the cell and the external environment.

Study of intensity of processes of restoration of physical health, genital tract and the functions of the internal reproductive organs of cows indicates that high-productive cows in the control group compared to low-productive ones the duration of postpartum resumption of ovulatory cycles and the service period was more respectively on 15 and 13 days (table. 4). 
4. Indicators of reproductive function of cows $(n=10, M \pm m)$

\begin{tabular}{|l|c|c|c|c|}
\hline \multirow{2}{*}{\multicolumn{2}{|c|}{$\begin{array}{l}\text { The studied } \\
\text { parameters }\end{array}$}} & \multicolumn{4}{c|}{ Group of cows } \\
\cline { 2 - 5 } & \multicolumn{2}{|c|}{ low productivity } & \multicolumn{2}{c|}{ high productivity } \\
\cline { 2 - 5 } & control & control & control & control \\
\hline $\begin{array}{l}\text { The period of postpartum resump-tion of } \\
\text { ovulatory cycles, days }\end{array}$ & $49,0 \pm 3,20$ & $38,8 \pm 3,44^{*}$ & $63,7 \pm 3,19$ & $44,9 \pm 3,64^{*}$ \\
\hline $\begin{array}{l}\text { Fertilization from the first insemination, \% } \\
\text { Duration of service period, days }\end{array}$ & 40,0 & 50,0 & 40,0 & 60,0 \\
\hline
\end{tabular}

The introduction of aloe extract reduces the duration of postpartum resumption of ovulatory cycles and service period in high-yielding cows, respectively, at 19 and 28 days, low productive ones at 10 and 19 days and increases fertility from the first insemination on 10.0 and $20.0 \%$.

\section{Conclusions.}

For the actions of aloe extract in erythrocytes of cows for 5-7 days before calving and 10 to 14 days after it increases the content of unsaturated fatty acids $(p<0,05-0,01)$. The content of polyunsaturated fatty acids increases at the expense $\omega-3$ and $\omega-6$ acids. Because blood erythrocytes do not use fatty acids for energy needs, these changes indicate the influence of aloe extract on the function of cell membranes.

The introduction of aloe extract for 25-30 days before calving has a positive effect on the course of the postpartum period, restoration of the full sexual cycles and fertilization.

\section{Bibliography}

1. Jablons'kyj V.A. Khomyn S.P., Zaviriukha V.I. et al. (2009). Biotehnologichni i molekuljarno-genetychni osnovy vidtvorennja tvaryn. L'viv: Afisha. 218 p.

2. Nezhdanov A.G. Lobodin K.A., Safonov V.A., Kochura M.N. (2008). Sistema ocenki i reabilitacii rannih narushenij fiziologicheskih funkcij reprodukcii zhivotnyh. Mezhdunarodnyj vestnik veterinarii. № 3. P. 13-15.

3. Amin A., Toth S., Gere T., Gere S. (2000). Relationships between milk production and productive and reproductive periods in different selection indices. Bull. of the Szent. Istvan. Univ. Godollo. P. 195-206.

4. Garanovych I.I. (1997). Imunnyj status velykoi' rogatoi' hudoby v krytychni periody. Fiziologichnyj zhurnal. № 3-4. P. 19-24.

5. Kurtjak B.M. (2001). Fiziologo-biohimichni osoblyvosti suhostijnogo periodu v koriv. Biologija tvaryn. T. 3, № 1. P. 34-40.

6. Fedoruk R.S., Kravciv R.J. (2003). Fiziologichni mehanizmy adaptacii' tvaryn do umov seredovyshha. Biologija tvaryn. Vol. 5. - № 1-2. - P. 75-82.

7. Kvachov V.G., Kassich A.Ju. (1991). Immunodeficitnye sostojanija i in korrekcija u sel'skohozjajstvennyh zhivotnyh. Sel'skohozjajstvennaja biologija. № 2. P. 105-114.

8. Afonina G.V., Kuchak N.A. (2000). Lipidy, svobodnye radikaly i immunnyj otvet. Kyiv. 258 p.

9. Garcia M., Greco L.F., Santos J.E.P., Staples C.R. (2011). Effect of linoleic acid supplementation to Holstein dams and calves on immune measures of calves. J. Dairy Sci. Vol. 94 (E-Suppl. 1). P. 200-211.

10. Silvestre F.T., Carvalho T.S., Francisco N. et al. (2011). Effects of differential supplementation of fatty acids during the peripartum and breeding periods of Holstein cows: I. Uterine and metabolic responses, reproduction, and lactation. J. Dairy Sci. Vol. 94. P. 189-204.

11. Mattos R. Staples C.R., Thatcher W.W. (2000). Effects of dietary fatty acids on reproduction in ruminants. Rev. Reprod. 2000. Vol. 5. P. 38-45.

12. Santos J.E.P., Greco L.F., Garcia M. et al. (2013). The role of specific fatty acids on dairy cattle performance and fertility. The 24th Annual Ruminant Nutrition Symposium, Gainesville, FL, February 5-6, P. 73-89. 
13. Parks C.A., Brett N.R., Agellon S. et al. (2017). DHA and EPA in red blood cell membranes are associated with dietary intakes of omega-3-rich fish in healthy children. PLEFA. Vol. 124. P. 11-16.

14. Thiele O., Plotkin J., Imre S. (1979). Lipid pattern of erythrocyte membrane of calf and adult cattle. Vol. 26. P. 425-431.

15. Fedorov Ju. N. (2005). Immunokorrekcija: primenenie i mehanizm dejstvija immunomodulirujushhih preparatov. Veterinarija. № 2. P. 3-6.

16. Chow J.T-N., Williamson D.A., Yates K.M., Goux W.J. (2005). Chemical characterisation of the immunomodulating polysaccharide of Aloe vera. L. Carbohydr. Res. Vol. 340. P. 1131-1142.

17. Im S.A., Oh S.T., Song S. et al. (2005). Identification of optimal molecular size of modified Aloe polysaccharides with maximum immunomodulatory activity. Int. Immunopharmacol. Vol. 5. P. 271-279.

18. Rivis J.F. Fedoruk R.S. (2010). Kil'kisni hromatografichni metody vyznachennja okremyh klasiv lipidiv i zhyrnyh kyslot u biologichnomu materiali. L'viv: Spolom, $109 \mathrm{p}$.

19. Izvekova V.A. (1991). Lipidy membran i funkcii immunokompetentnyh kletok $v$ norme i patologii. Uspehi sovremenoj biologii. T. 111, vip. 4. P. 577-590.

20. Kvachov V.G., Sokyrko T.O. (2003). Lipidnyj gomeostaz membran i imunologichna kompetentnist' mononuklearnyh fagocytiv, mehanizmy vzajemozv'jazku i novi pidhody do rozrobky imunoaktyvnyh preparative. Biologija tvaryn. T. 5, № 1-2. P. 83-88.

21. Rojt A. Brostoff Dzh., Mejl D. (2000). Immunologija: translation from english. Moskva: Mir, $581 \mathrm{p}$.

22. Ansell G.B, Hawthorne J.N. (2000). Aggregation and Fusion of vusicles composed of n-palmitoyl derivatives of membrane phospholipids. J. Lipids. Vol. 35. - P. 513-524. 